\title{
Correction to: Southern Patagonia, Tierra Del Fuego, the South Atlantic and The Antarctic Lands Within Global Strategies
}

\section{Correction to:}

Chapter 5 in: L. I. de Lasa and M. T. Luiz, The Southernmost

End of South America Through Cartography, The Latin

American Studies Book Series, https://doi.org/10.1007/978-3-030-65879-3_5

The original version of the book was published with an error in processing the Figs. 5.12, 5.22 and 5.25.

The chapter and the book have been updated with the changes. 